\title{
Before the Ink Is Dry: Does Sustainability Reduce Earnings Management? Theoretical Perspective
}

\author{
Ahmad Alwadhan \\ Aston Business School, Birmingham, UK \\ Suzan Abed (Corresponding author) \\ University of the District of Columbia, Washington, DC, USA \\ E-mail: suzan.abed@udc.edu
}

Received: July 29, 2021 Accepted: September 25, 2021 Published: September 28, 2021

doi: 10.5296/ijafr.v11i3.18888

URL: https://doi.org/10.5296/ijafr.v11i3.18888

\begin{abstract}
This paper reviews the field of sustainability to develop insights into earnings management studies and outline future research opportunities. We find that most previous studies use integrated reports measured by three dimensions of social, economic and environmental sustainability. These three dimensions are interrelated and communicate with each other to formulate the definition of sustainability. And the sustainability report should provide a balanced disclosure of sustainability performance, including both positive and negative contribution. This paper offers an insightful analysis into sustainability disclosure to support the analysis of IR benefits to balance the current literature that overlooks the benefits of IR.
\end{abstract}

Keywords: Integrated reporting, Sustainability, Earnings management, Literature review, Synthesis analysis

\section{Introduction}

Each and every one can debate that ultimate target of any business is to make a profit for the owners. The benefit of shareholders regularly has the lion's share of whatever the research in management disciplines. In the last decades of accounting aeon, new arguments punch the clock to override the frontiers of this debate. Among these arguments are the ones associated with the environmental and social consequences of any business which turns the cards of accounting literature to a whole new level of thinking. A paramount question in the relevant literary works has come to light to identify what are the consequences of businesses activities on humankind and environment. This issue and many others crack the glass to question firm's capacity to contribute to the welfare of society and sustain the environment and its natural resources. A front position of accounting in this arena of research is how the business reports about its social and environmental performance .Terms such as corporate social responsibility 


\section{Mll Macrothink}

International Journal of Accounting and Financial Reporting ISSN 2162-3082 2021, Vol. 11, No. 3

(CSR), environmental accounting, and corporate governance has been keeping one's eyes on in the accounting literature. These terms, in the thick of others, have been measured and examined to grasp its determinants and its impacts on many aspects, such as financial performance, earnings quality, access to finance and so forth. This has been achieved to prove if its reward to companies to be more responsive to open doors for more efforts for the welfare society and environment beyond just making profits. The proceeds of such literature motivated the scholars to a significant concern related to the heart of this debate. That is, any firm financial report must be comprehensive to cover all of its activities, strategies, financial performance and so forth. In other words, the financial reporting of the company must reveal what called the business model that explains how the firms create profit and its consequences on the society and environment. The term integrated reporting has arrived to satisfy this call by requiring company's financial reporting system to be integrated into all aspects. By undertaking this, researchers claimed that such reporting would include the indicators to the firm's capability to sustain

In the long run, the appearance of corporate sustainability brain wave is principally associated to the Brundtland report's interpretation of "sustainable development" as "development that meets the needs of the present without compromising the ability for future generations to meet their needs" (WCED, 1987, p. 43). These arguments make the scenes for hot area in the field of accounting research in the sustainability reporting. This is recognized especially after the scandals of corporations such as Enron and WorldCom and after the collapse of financial markets in 2008.

\section{Literature Review}

The pillars of expert accounting bodies and other international organizations have contributed and take the oath for integrated reporting. These bodies, naming just a few, according to Owen (2013, p.340) include, "World Business Council for Sustainable Development, the World Resources Initiative, the United Nations Conference on Trade and Development (UNCTAD), the Global Reporting Initiative (GRI), the International Corporate Governance Network, the International Federation of Accountants (IFAC) and the International Integrated Reporting Committee (IIRC)".These bodies and organizations give a hand to the diffusion of IR by putting the current map of financial reporting in question since such bodies and organizations attempt to throw a spotlight on IR.

The interpretation alongside with the definition of IR yet has a notable room for debates. For example, Dumay et al. (2016) observed through examining the literature related to IR that there is an absence of crucial perception of IR. However, according to the IIRC, the integrated reporting makes sense by IIRC (2013, p.1). "Organizations are using IR to communicate a clear, concise, integrated story that explains how all of their resources are creating value. IR is helping businesses to think holistically about their strategy and plans, make informed decisions and manage key risks to build investor and stakeholder confidence and improve future performance. It is shaped by a diverse coalition including business leaders and investors to drive a global evolution in corporate reporting". 
Scholars seek to conceptualize IR to present more cleared interpretation of IR. For instance, Abeysekera (2013) contended that integrated reporting attempt to consolidate the mixture of information regarding any entity activities in common principles with unified purposes. She reported that the primary goal of integrated reporting is to assist stakeholders to evaluate whether a company can generate and sustain its value over time.

Moreover, Adams (2015) acknowledges that IR is a step to another horizon of financial reporting. This is due to the nature of IR that liberalize from the mainstream accounting to think how firm create value and sustain in the long term. By the same token, the fundamental point is how to report about this value creation and sustainability. Owen (2013, p.340) argued that "IR provides information on financial and non-financial performance in a single document, showing the relationship between financial and non-financial performance and how these inter-related dimensions are creating or destroying value for shareholders and other stakeholders". Reimsbach et al. (2018) claimed that the assurance effect was weaker in the case of integrated reporting compared to separate reporting

However, a question can be laid on the table to grasp what IR includes beyond the contemporary and traditional financial reporting. The answer may be complicated and up for discussion taking into account that the perception of what IR is debatable. But be that as it may, Flower (2015) provides a critical review in the heart of IIRC initiative and IR proposed framework. He clarified that IR would include traditional financial statements, management commentaries, governance and remuneration reports and sustainability reports. Beside this, the global reporting initiative (GRI) provides guidelines for IR. These guidelines anticipate companies' reports to consolidate descriptions of business strategy purposes, the company biography, the management plan, and a list of the main performance indicators. Based on IIRC framework of IR, Flower (2015) developed a better understanding of IR by explaining in details the framework of IR. He addressed six

Categories of capital covering the financial capital, manufactured capital, human capital, intellectual capital, natural capital and social capital. He critiques this framework because the barriers between the six capitals are foggy. For example, the workforce can be human or intellectual. Also, some of these capitals not owned by the firm, for instance, the capital of society which made the task to preserve the harmony between these capitals is critical. He argued that the fundamental view of IR is how the organization creates value, through actions performed, by measuring the rise in the capitals less the reduction in the same capitals.

Recent studies in IR such as (Dumay et al., 2016; Perego et al., 2016) by all means acknowledge that IR still in early years which make the research possibilities in IR need the qualitative approach, not the quantitative methods. Perego et al. (2016) pay attention to an important aspect that the academics literary works shut eyes on the benefits of IR and completely concentrated on the cost of IR. Indeed, they put a good word to support the analysis of IR benefits to balance the current literature that overlooks the benefits of IR. More than that, they made a valuable invitation to studies in a related field such as sustainability, environmental, social and governance (ESG) because they will help IR development. 
In a different manner, Dumay et al. (2016) fought for IR to be the fate of corporate reporting in the next years. They shed the light on some ideas to conclude that observing IR practice will not be sufficient since the call to understand the IR is needed. At last (Dumay et al., 2016; Perego et al., 2016) be of the same mind that there is no robust evidence regarding IR benefits which makes research in such field just around the corner.

The term sustainability by all means interrelated with IR .In fact; some researchers, such as Flower (2015) contended that sustainability reporting comes straight from shoulders of IR since delivering such IR guarantee that companies sustain its capitals for future generations that embody the idea of sustainability. Recently published papers show and tell that sustainability reporting in the body of IR .For example, Abeysekera (2013) mentioned that sustainability reporting is part of IR that measure sustainable performance in many dimensions alongside with other aspects of IR. Adams (2015) claimed that IR is not merely to report on sustainability. But also to include how firm create value and how it reports about this value creation side by side with sustainability.

\section{Sustainability Reporting}

Dumay et al. (2016) argued consolidating the social, environmental and economic aspects in the financial reporting drop the anchor over the last 25 years. The studies about the financial reporting are uncountable. But be as it may, in the contemporary era, the financial reporting is reconstructed, and more disclosures are escalated. Gray (2006) argued that social, environmental and sustainability reporting is descending from the financial reporting model. He perceived that this argument is not among the traditional mainstream accounting literature. Strictly speaking, he contended that the ethical perspective of financial reporting is about the outcomes of such reporting, not the reporting in the flesh. This means that the financial reporting will influence the stakeholder choices about a particular entity which induce to transferring funds to entities that economically outperformed other entities. He tried to convey the perception that social, environmental and sustainability reporting strive to become the alternative accountings to serve the whole society. Over and above, Abeysekera (2013) argued that investors not only interested in the financial and non-financial information, but they also crave to understand how their investment influences the environment and society in overall. This boost the desire for increased sustainable performance which promotes the firms to adjust how they utilize their sources and how they report on it. If the company missed informing users about such information, it's expected not to survive in the long run mainly that highly rating companies in such issues drag more investor (Antolín et al., 2016).

An underlying issue here is how sustainability reflected. Scholars are discussing sustainability to incorporate appropriate " dimensions " to reflect what we mean when we say, for example, firm X is more sustainable than firm Y. For instance, Abeysekera (2013) content that sustainability reporting is part of IR that measure sustainable performance in six dimensions incorporate economic, environmental, labor activities, human rights, society, and product responsibility. Amini and Bienstock (2014, p.16) submit a framework for sustainability that includes five dimensions comprise of "level business application and communication of sustainability activities/performance (such as, the strategies undertook to 
move closer to sustainability), the scope of organizational focus (such as, the company supply chain incorporating suppliers and customers), sustainability-oriented innovation (such as, how the firm combine the innovation with sustainability), economic/ecological-environmental/equity social emphasis (mirror the degree to which an organization embraces all aspects of sustainability, economic, ecological environmental and equity-social), and compliance stance (reflects how well sustainability in the organization shape the regulations and proactively complying with existing regulations)". These levels were combined with the sophistication of the organization, and each level alters across the degree of sophistication.

To clear the way for deeper understanding what is sustainability reporting, terms associated with the arena of sustainability reporting have kicking around in the recent decade. These terms include, among others, corporate social responsibility (CSR), environmental accounting, and the triple bottom line accounting (TBL). Dumay et al. (2016), acknowledged that terms such as social responsibility, environmental accounting, corporate governance, sustainability reporting and the triple bottom line accounting ways of thinking, perceive any accounting entity as a reporting entity that operates not beyond a particular framework. Additionally, they argued that sustainability grows to include the ecological and social justice.

With no strings attached, the related literature, such as (Owen, 2013; Aragon, 2013; Amini and Bienstock, 2014; Montiel and Delgado, 2014; Antolín et al., 2016) made a consistent argument that The TBL, as the measurement of sustainability, is the fundamental perspective about sustainability. For example, Owen (2013) pointed the terms, sustainability accounting, TBL and corporate social responsibility (CSR) used interchangeably. However, he explained that the interpretation of sustainability based on the TBL is mainly due to the incorporation of the economic dimension arguing that economic dimension brings down the curtain on long established value creation to preserve firms capitals. Additionally, a considerable portion of academics and scholars identified sustainability to be mirrored by the three dimensions and they use the term TBL and sustainability reciprocally (Montiel and Delgado, 2014). Another perspective sees that stakeholder recognized the measurement of corporate sustainability is based on the three dimensions of TBL (Antolín et al., 2016).

The term TBL, in the first place, proposed by Elkington (1998) by describing TBL as the social, economic and environmental sustainability. This three dimensions measure the achievement of the company rather than the focus on economic sustainability only. These three dimensions are interrelated and communicate with each other, and the company cannot separate, for example, the economic dimension, from other dimensions.

To give the main point, the reported literature showed that when we say sustainability, primarily, we say three dimensions combine the economic, social and environmental dimensions. Furthermore, a relative consensus has been developed on what sustainability represents despite some controversial perspective here and there in what exactly sustainability means. Be that as it may, to get ink for the understanding of sustainability reporting, definitions of sustainability reporting have been formed to convey the perspective of sustainability reporting. For instance, global reporting initiative has defined sustainability 
reporting as "the practice of measuring, disclosing, and being accountable to internal and external stakeholders for organizational performance towards the goal of sustainable development. A sustainability report should provide a balanced and reasonable representation of the sustainability performance of the reporting organization, including both positive and negative contributions', In like manner, Gray and Milne (2002, p.3) seek to conceptualize sustainability reporting by characterizing it as a "complete and transparent statement about the extent to which the organization had contributed to - or, more likely, diminished- the sustainability of the planet....to have a detailed and complex analysis of the organization's interactions with ecological systems, resources, habitats, and societies, and interpret this in the light of all other organizations' past and present impacts on those same systems". Likewise, Daub (2007, p.76) developed a definition of sustainability reporting by arguing that sustainability reporting is a report "must contain qualitative and quantitative information on the extent to which the company has managed to improve its economic, environmental and social effectiveness and efficiency in the reporting period and integrate these aspects in a sustainability management system".

\section{Earning Management}

Earnings are another name for the bottom line or net income. Earnings are important signs of the Entities business performance. For instance, Francis et al. (2003) explained that earning are more closely associated with stock prices than are cash flow, sale or other financial statement data. There are numerous description of earning that are universally understood in the academic and professional literature. Dechow et al. (2010) stated that earnings, in general, can be connected to three categories, firstly is the properties of earnings, secondly investor responsiveness to earnings and thirdly is the external indicators of earnings misstatement. They recognized earnings management under the first category, the properties of earnings, which represented earnings management among the main issue related to the concept of earnings. Healy and Wahlen (1999, p.368) define earnings management as "Earnings management occurs when managers use judgment in financial reporting and in structuring transactions to alter financial reports to either mislead some stakeholders about the underlying economic performance of the company or to influence contractual outcomes that depend on reported accounting numbers". Lee and Hwang (2019) highlighted that earnings management has an impact on the sustainability of individual financial firms through the reliability of financial statements. Chen and Hung (2020) documented that firm engage in CSR reduce earnings management using CSR index proposed by Chen et al. (2003). Ayu et al. (2020) revealed that more cost on environmental and social information disclosure can generate greater opportunities for corporations. Obeng et al. (2020) highlighted that earnings quality is significantly higher for IR firms than non-IR firms.

\section{Problem Statement}

At this point, the problem of the study, to some extent, cleared. That is, the academic works in sustainability reporting are "few" as demonstrated by several scholars. This offers an appealing field to study. Moreover, by lay eyes on the prior studies in conjunction with the relative consensus on what sustainability describe, it appears that accounting literature has 
been questioning one or, in few situations, two dimensions of sustainability which give directions to a gap in the associated literature meaningfulness to investigate by examining the three dimensions together.

This paper provides a synthesis of sustainability and earnings management by exploring the potential measure of Integrated report. It updates the recent achievements in the earnings management literature from an accounting perspective and explores the proposed measure of integrated report based on three dimensions of social, economic and environmental sustainability.

Scholars, such as (Antolín et al., 2016; Gray, 2006) claimed that notable portion of the studies that examined sustainability reporting have full-bodied the sustainability only on one of the dimensions of sustainability, on a large scale the environmental dimension, and overlooked the other aspects of corporate sustainability. The literature of sustainability separates the environmental and social dimension from the economic dimension. The lack of integration of all three dimension probably has handed over an inadequate perception about sustainability (Antolín et al., 2016; Gray and Milne, 2002; Aras and Crowther, 2009). Over and above, the empirical pieces of evidence on the advantages of sustainability still not completely examined, see for instance Chelli and Gendron (2013), which describe another gap call for an investigation. Finally, a necessity arises to understand what is the dimension concentrated by companies and how the interaction, if any, between the three dimensions occur. This study will contribute to the in circulation literature of sustainability reporting by, to a certain degree, several points. First, by feast eyes on social, economic and environmental dimensions as an integrated unit of information, it will convey a well-defined conceptualization of sustainability for stakeholders to facilitate the interpretation of performance made by a particular entity to sustain its value over time. Second, it will frame up the diffusion of sustainability reporting among firms which, in turn, assist the decision-making process to put one's finger on the need of posing more regulations to improve sustainability reporting. Third, examining sustainability reporting supposed to make the scene for enhancing integrated reporting by distinguishing what is missed in sustainability reporting to compass the suitable status recommended by integrated reporting.

The previous academic work put on the line a mixed bag of instruments to measure sustainability reporting. Yet to measure sustainability performance, it is necessary to acknowledge that very few studies have developed a widespread model for sustainability performance. This passes the word that the measurement of sustainability performance is a little bit challenging. However a study conduct by $\mathrm{Ng}$ and Rezaee (2015) is considered the first study to develop a comprehensive model to measure sustainability performance.

Within the universe of industries, the brain wave of sustainability has, in many instances, escalated quickly in business agendas as growing numbers of firms frequently acknowledge sustainability in different countries. Market-based economy, corporate control is a crucial perspective to stakeholders. Businesses, now and then, have a considerable volume of stakeholders who own minor stakes and build their investment choices upon their interpretation of information. This will be within the view by considering that firms have 


\section{MInstitute ${ }^{\text {Min }}$}

International Journal of Accounting and Financial Reporting ISSN 2162-3082

faith in their stakeholders to finance their projects. For these reasons, stakeholders have major pressure on companies to disclose financial information side by side with non-financial information to encompass all relevant features of their activities (Adams et al., 1998; Jensen and Berg, 2011).

The history of UK in the social and environmental aspect of sustainability can be traced from more than a decade. Several accounting bodies in UK had a growing interest regarding sustainability. For, instance, in 1991, the Association of Chartered Certified Accountants (ACCA) announced the UK environmental reporting award. This award changed in 2001 to be the sustainability reporting award. Birkin and Jørgensen (1994) conducted a comparative study to exhibit the environmental reporting in UK. They found that all sampled companies in UK have issued a separate report for environmental concerns. Adams et al. (1998) found that UK companies have very high information about social responsibility in their annual reports by comparing to other countries as they strive to improve thoughts and credibility of their business. (KPMG, 2015) report on corporate responsibility showed that the UK amongst in the forefront counties in sustainability reporting and integrated reporting. For instance, UK has compulsory corporate responsibility regulations. Also, more than $90 \%$ of UK companies have consolidated corporate responsibility information in their annual reports and more than $10 \%$ of these companies say they follow the integrated reporting approach which includes sustainability reporting.

Lukomnik et. al. (2018) reports that $78 \%$ of the S\&P 500 issued a sustainability report for the most recent reporting period, most with environmental and social performance metrics.

Hong and Andersen (2011) shows that more socially responsible firms have higher quality accruals and less activity-based EM, both of which impact financial reporting quality. Chih et al. (2008) document that with a greater commitment to CSR, the extent of earnings smoothing is mitigated. They predict that a firm with CSR in mind tends not to smooth earnings, and displays less interest in avoiding earnings losses and decreases. It is, however, prone to engage in more earnings aggressiveness, but this tendency can be mitigated in a country with strong legal enforcement. Shleifer (2004) interprets that earnings manipulation, occurs less often in corporations with a strong commitment to social responsibility. Therefore, we may predict that firms with a high degree of CSR may tend to smooth earnings to ensure that reported earnings are more predictable. This is referred to as the predictable earnings hypothesis because a CSR minded firm is inclined to smooth earnings. However,

\section{Conclusion}

The importance sustainability in accounting education has increased significantly over the past years. However, the definition of sustainability and CSR are commonly and interchangeably used in academic researches. This paper represents a novel contribution as it is believed to constitute on the previous studies of integrated reports and earnings management to draw the two literatures together within the context of a single paper. We reviewed the definition and the use of sustainability and corporate social responsibility (CSR) in previous studies, and we found that most of the previous studies focus on three dimensions of sustainability related to social, economic and environmental factors. These three 
dimensions are interrelated and communicate with each other to formulate the definition of sustainability. However, previous studies on sustainability and earning management have concentrated on one dimension of sustainability. Therefore, this study frames future research to empirically examine the efficiency of the three dimension of sustainability on earnings management. The future scholars should also address the relationship of cost of disclosure, earning administration, and the three dimensions of sustainability, with the firm economic performance in the context of more than one industry.

\section{References}

Abeysekera, I. (2013). A Template for Integrated Reporting. Journal of Intellectual Capital, $14(2), 227-45$.

Adams, C. (2015. The International Integrated Reporting Council: A Call to Action. Critical Perspectives on Accounting, 27, 23-28.

Adams, C., Hill, W., \& Roberts, C. (1998). Corporate Social Reporting Practices in Western Europe: Legitimating Corporate Behavior?. The British Accounting Review, 30(1), 1-21.

Amini, M., \& Bienstock, C. (2014). Corporate Sustainability: An Integrative Definition and Framework to Evaluate Corporate Practice and Guide Academic Research. Journal of Cleaner Production, 76, 12-19.

Antolín-Lopez, R., Delgado-Ceballos, J., \& Montiel, I. (2016). Deconstructing Corporate Sustainability: A Comparison of Different Stakeholder Metrics. Journal of Cleaner Production, 136, 5-17.

Aragon, J. (2013). Beyond Ourselves: Building Bridges to Generate Real Progress on Sustainability Management Issues. Organization and Environment, 26, 3-6.

Aras, G., \& Crowther, D. (2009). Corporate Sustainability Reporting: A Study in Disingenuity?. Journal of Business Ethics, 87, 279-88.

Ayu, M., Gamayuni, R. R., \& Urbański, M. (2020). The impact of environmental and social costs disclosure on financial performance mediating by earning management. Polish Journal of Management Studies, 21.

Bansal, P. (2005). Evolving Sustainably: a Longitudinal Study of Corporate Sustainable Development. Strategic Management Journal, 26(3), 197-218.

Birkin, F., \& Jørgensen, H. B. (1994). Corporate Environmental Reports as Wealth Appropriation Statements. Environmental Management and Health, 5(3), 23-27.

Chatterji, A., Durand, R., Levine, D., \& Toubou, S. (2016). Do ratings of firms converge? Implications for managers, investors and strategy researchers. Strategic Management Journal, $37(8)$.

Chen, R. C., \& Hung, S. W. (2021). Exploring the impact of corporate social responsibility on real earning management and discretionary accruals. Corporate Social Responsibility and Environmental Management, 28(1), 333-351. 


\section{MInstitute ${ }^{\text {Mink }}$}

International Journal of Accounting and Financial Reporting

ISSN 2162-3082

Chih, H. L., Shen, C. H., \& Kang, F. C. (2008). Corporate social responsibility, investor protection, and earnings management: Some international evidence. Journal of Business Ethics, 79(1), 179-198.

Daub, C. (2007). Assessing the Quality of Sustainability Reporting: An Alternative Methodological Approach. Journal of Cleaner Production, 15(1), 75-85.

Dechow, P., Ge, W., \& Schrand, C. (2010). Understanding Earnings Quality: A Review of the Proxies, their Determinants and their Consequences. Journal of Accounting and Economics, 50(2-3), 344-401.

Dhaliwal, D. S., Li, O. Z., Tsang, A., \& Yang, Y. G. (2011). Voluntary Nonfinancial Disclosure and the Cost of Equity Capital: The Initiation of Corporate Social Responsibility Reporting. The Accounting Review, 86(1), 59-100.

Dumay, J., Bernardi, C., Guthrie, J., \& Dematrini, P. (2016). Integrated Reporting : a Structured Literature Review. Accounting Forum, 166-85.

Dyllick, T., \& Hockerts, K. (2002). Beyond the Business Case for Corporate Sustainability. Business Strategy and the Environment, 11(2), 130-41.

Elkington, J. (1998). Partnerships from Cannibals with Forks: The Triple bottom line of 21st-Century Business. Environmental Quality Management, 8(1), 37-51.

Figge, F., Hahn, T., Schaltegger, S., \& Wagner, M. (2002). The Sustainability Balanced Scorecard - Linking Sustainability Management to Business Strategy. Business Strategy and the Environment, 11, 269-84.

Flower, J. (2015). The International Integrated Reporting Council: A Story of Failure. Critical Perspectives on Accounting, 25, 1-17.

Francis, J., Francis, J., \& Vincent, L. (2003). The Relative and Incremental Explanatory Power of Earnings and Alternative (to Earnings) Performance Measures for Returns. Contemporary Accounting Research, 20(1), 121-64.

Gray, R. (2006). Does Sustainability Reporting Improve Corporate Behavior?: Wrong Question? Right Time?. Accounting and Business Research, 36(1), 65-88.

Gray, R., \& Milne, M. (2002). Sustainability Reporting: Who's Kidding Whom?. Chartered Accountants Journal, 81(6), 66.

Hamann, P. M., Schiemann, F., Bellora, L., \& Guenther, T. W. (2013). Exploring the Dimensions of Organizational Performance: A Construct Validity Study. Organizational Research Methods, 16(1), 67-87.

Hart, S. (1995). A Natural-Resource-Based View of the Firm. The Academy of Management Review, 20(4), 986-1014.

Healy, P., \& Wahlen, J. (1999). A Review of the Earnings Management literature and its Implications for Standard Setting. Accounting Horizon, 13(4), 365-83. 
Hong, Y., \& Andersen, M. L. (2011). The relationship between corporate social responsibility and earnings management: An exploratory study. Journal of Business Ethics, 104(4), 461-471.

IIRC. (2013). The international Integrated Reporting framework. London.

Jensen, J. C., \& Berg, N. (2011). Determinants of Traditional Sustainability Reporting Versus Integrated Reporting. An Institutionalist Approach. Business Strategy and the Environment, 21(5), 299-316.

Kanagaretnam, K., Lobo, G. J., \& Whalen, D. J. (2007). Does Good Corporate Governance Reduce Information Asymmetry round Quarterly Earnings Announcements? Journal of Accounting and Public Policy, 26(4), 497-522.

Kim, Y., Park, M. S., \& Wier, B. (2012). Is Earnings Quality Associated with Corporate Social Responsibility?. The Accounting Review, 87(3), 761-96.

Kolk, A., Hong, P., \& Dolen, W. V. (2010). Corporate Social Responsibility in China: An Analysis of Domestic and Foreign Retailers' Sustainability Dimensions. Business Strategy and the Environment, 19, 289-303.

KPMG. (2015). International Survey of Corporate Responsibility Reporting 2015. Amsterdam.

Larcke, D. F., Richardson, S. A., \& Tuna, I. (2007). Corporate Governance, Accounting Outcomes, and Organizational Performance. The Accounting Review, 82(4), 963-1008.

Lee, M., \& Hwang, I. T. (2019). The effect of the compensation system on earnings management and sustainability: Evidence from Korea banks. Sustainability, 11(11), 3165.

Lukomnik, J., Kwon, S., \& Welsh, H. (2018). State of integrated and sustainability reporting 2018. In Harvard Law School Forum on Corporate Governance and Financial Regulation. $\begin{array}{llll}\text { Retrieved November } & \text { 21, } & \text { from }\end{array}$ http://corpgov.law.Harvard.edu/2018/12/03/state-of-integrated-andsustainability-reporting-20 $18 /$

Marrewijk, M. (2003). Concepts and Definitions of CSR and Corporate Sustainability: Between Agency and Communion. Journal of Business Ethics, 44, 95-105.

Matte, D., \& Moon, J. (2008). A Conceptual Framework for a Comparative Understanding of Corporate Social Responsibility. Academy of Management Review, 33, 404-24.

Montiel, I., \& Delgado-Ceballos, J. (2014). Defining and Measuring Corporate Sustainability: Are We There Yet?. Organization and Environment, 34(3), 1-27.

Ng, A., \& Rezaee, Z. (2015). Business Sustainability Performance and Cost of Equity Capital. Journal of Corporate Finance, 34, 128-49.

Obeng, V. A., Ahmed, K., \& Miglani, S. (2020). Integrated reporting and earnings quality: The moderating effect of agency costs. Pacific-Basin Finance Journal, 60, 101285. 


\section{Macrothink \\ International Journal of Accounting and Financial Reporting ISSN 2162-3082 2021, Vol. 11, No. 3}

Owen, G. (2013). Integrated Reporting: A Review of Developments and their Implications for the Accounting Curriculum. Accounting Education: An International Journal, 22(4), 340-56.

Perego, P., Kennedy, S., \& Whiteman, G. (2016). A Lot of Icing but Little Cake? Taking Integrated Reporting Forward. Journal of Cleaner Production, 136, 5364.

Reimsbach, D., Hahn, R., \& Gürtürk, A. (2018). Integrated reporting and assurance of sustainability information: An experimental study on professional investors' information processing. European Accounting Review, 27(3), 559-581.

Searcy, C. (2012). Corporate Sustainability Performance Measurement Systems: A Review and Research Agenda. Journal of Business Ethics, 107, 239-53.

Shleifer, A. (2004). Does competition destroy ethical behavior?. American Economic Review, 94(2), 414-418.

Spence, C., Husillos, J., \& Correa-Ruiz, C. (2010). Cargo Cult Science and the Death of Politics: A Critical Review of Social and Environmental Accounting Research. Critical Perspectives on Accounting, 21(1), 76-89.

WCED. (1987). Our common future. New York: Oxford University Press.

\section{Copyright Disclaimer}

Copyright for this article is retained by the author(s), with first publication rights granted to the journal.

This is an open-access article distributed under the terms and conditions of the Creative Commons Attribution license (http://creativecommons.org/licenses/by/4.0/) 